Running Head: STREET GANG MEMBERS IN CUSTODY

\title{
Psychological and Behavioral Characteristics That Distinguish Street Gang Members in Custody
}

Emma Alleyne, Jane L. Wood, Katarina Mozova, and Mark James Centre of Research and Education in Forensic Psychology (CORE-FP)

Please cite as follows:

Alleyne, E., Wood, J.L., Mozova, K., \& James, M. (2015). Psychological and behavioral characteristics that distinguish street gang members in custody. Legal and Criminological Psychology. DOI: 10.1111/lcrp.12072

Correspondence concerning this article should be addressed to Emma Alleyne, Centre of Research and Education in Forensic Psychology, School of Psychology, Keynes College, University of Kent, Canterbury, Kent, CT2 7NP, England. E-mail:

E.K.A.Alleyne@kent.ac.uk 


\begin{abstract}
Purpose. Using social dominance theory, the primary aim of this study was to examine the attitudes and beliefs that reinforce status hierarchies and facilitate aggressive behavior within and between gangs. The aim was also to determine whether these socio-cognitive processes distinguished gang-involved youth from non-gang offenders in a custodial setting.
\end{abstract}

Methods. Gang-involved youth and non-gang offenders were recruited from a Young Offender Institution (YOI) located in the United Kingdom. Questionnaires assessing psychological (i.e., moral disengagement strategies, anti-authority attitudes, hypermasculinity, and social dominance orientation) and behavioral (i.e., group crime) characteristics were administered individually. We hypothesized that gang-involved youth would be affiliated with groups who engaged in more criminal activity than non-gang offenders, and that they would report higher levels of endorsements than non-gang youth across all of the psychological measures.

Results. We found that gang-involved youth were affiliated with groups who engage in more crimes than non-gang offenders. We also found that social dominance orientation was an important factor related to gang involvement along with measures assessing group-based hierarchies such as hypermasculinity, anti-authority attitudes, and the moral disengagement strategies displacement of responsibility, dehumanization, and euphemistic labelling.

Conclusions. These findings fit within a social dominance theoretical framework as they highlight key psychological factors that feed into perceived status-driven hierarchies that distinguish gang members from other types of offenders. These factors could be key to developments in treatment provision within custodial settings. 
Running Head: STREET GANG MEMBERS IN CUSTODY

\section{Psychological and Behavioral Characteristics That Distinguish Street Gang Members in Custody}

Gang members are responsible for a high volume and wide range of offending, especially violent offending (e.g., Klein \& Maxson, 2006). The literature also supports that incarcerated gang members are also more likely than non-gang offenders to engage in misconduct and aggressive behavior within prison establishments (Drury \& DeLisi, 2011; Scott, 2014). Findings such as these are not limited to the North American context. Similar findings have been documented in Europe (Gatti, Haymoz, \& Schadee, 2011; Klein Weerman, \& Thornberry, 2006), Asia (Chu, Daffern, Thomas, \& Lim, 2012; Pyrooz \& Decker, 2013) and Australia (White, 2006). But this research has only recently emerged in comparison to the US-based literature. More international research is needed in this area to fully grasp why young people join gangs, which factors should be targeted to facilitate desistance and rehabilitation, and whether these factors transcend national boundaries.

What we find in the literature is that the reasons why young people join gangs are varied, and some would argue that "the street gang culture is something young people have created themselves for themselves" (Shropshire \& McFarquhar, 2002, p. 3). This culture has manifested from a variety of social and contextual factors such as neighborhood, family, school and peer influences (Alleyne \& Wood, 2014). Further to the environmental and individual factors related to gang involvement, Short and Strodtbeck (1965) argued that group norms and group processes not only attract youth to join street gangs, but also sustain and maintain gang membership. Yet until recently, the inter- and intra-group processes well established in the social psychological literature have not been examined within the context of street gangs (Wood \& Alleyne, 2012). So the purpose of the current study was to examine the extent to which group-based attitudes and beliefs associated with aggressive and violent behavior (i.e., social dominance orientation, hypermasculine values, anti-authority attitudes 
Running Head: STREET GANG MEMBERS IN CUSTODY

and moral disengagement) were prevalent in gang-involved youth and whether these sociocognitive processes distinguish gang-involved youth from non-gang offenders in a Young Offenders Institution (YOI).

\section{Theoretical Framework}

Psychological theory has been used to explain the group processes that encourage young people to join or form groups; so far to argue that young people join groups to alleviate role and identity confusion experienced during adolescent development (Vigil, 1988). Evidence suggests young people join or form groups with peers who share attitudes and beliefs that feed into prototypical behavior, thus the perceived support they receive when engaging in such behavior (e.g., gang-related crime) reinforces the shared attitudes in a form of reciprocity (Viki \& Abrams, 2013).

Theoretical advances on group formation have also helped in explaining the dynamics behind group formation and also the structural and instrumental purpose driving group conformity and cohesion. For example, some literature supports that intergroup competitive and discriminatory behavior can be provoked by the mere awareness of the presence of an outgroup (i.e., social identity theory; Tajfel \& Turner, 1979). Social identity theory was further expanded upon by incorporating a fundamental motivating principle such as status. It can be argued that everyday society is structured around group-based structural hierarchies (e.g., race, gender, class, etc.), and in each instance there is a perceived (and/or actual) dominant, high-status group and a subordinate, low-status group (Sidanius \& Pratto, 1999). Sidanius and Pratto (1999) conceptualized social dominance theory to explain why and how individuals behave in a way that enhances, or at least reinforces, their place (and the place of their group) within an overarching social hierarchy. They argued that many hierarchies can be socially and arbitrarily constructed in response to the situational context (e.g., street gangs 


\section{Running Head: STREET GANG MEMBERS IN CUSTODY}

can be considered a response to marginalization - Hagedorn, 2005). Therefore, our social dominance orientation (i.e., the degree to which we endorse hierarchical distinctions) may influence our behavior via our motivation to achieve and maintain a high status (Sidanius \& Pratto, 1999). If this is the case, this could result in a binary intergroup competitive and discriminating ideology (e.g., 'us' vs 'them').

There is some evidence from the gang literature that supports social dominance theory. For example, we know for some youth that the temptation to join gangs is because gangs offer the potential to gain respect and status (Alleyne \& Wood, 2010; Anderson, 1999; Klein \& Maxson, 2006). This in itself suggests a status hierarchy that gang members endorse, perhaps demonstrating a social dominance orientation. Theoretically-speaking, this orientation would be dependent on several distal (e.g., education, peers, neighborhood, family, etc.) and proximal (e.g., legitimizing myths such as hypermasculine values, moral disengagement, etc.) factors. These proximal factors shed a unique light on the individual differences between youth who join gangs and those who do not join gangs and these differences seem to have eluded the gang literature until very recently (Wood \& Alleyne, 2010).

There are gender-based asymmetries exemplified in the literature whereby male gang members dominate the activities of the gang. Arguably, preconceived gender roles can manifest in attitudes and beliefs (i.e., legitimizing myths) regarding what is masculine; for example, "if one is not a real man, one is diminished as a person" (Anderson, 1999, p. 91). Research supports a link between hypermasculinity and aggressive behavior generally (Archer, 2010; Hannan \& Burkhart, 1993) and in gang members specifically (Lopez \& Emmer, 2002). In other words, the notion of hypermasculinity encompasses the asymmetrical gender-based hierarchy outlined in social dominance theory and its manifestation (i.e., interpersonal violence, pursuit of status, social dominance and devaluation of female roles; 
Running Head: STREET GANG MEMBERS IN CUSTODY

Burk, Burkhart, \& Sikorski, 2004) is characteristic of male gang members (Lopez \& Emmer, 2002).

Group-based hierarchies can also be perceived between young people and figures of authority. Past research has highlighted the 'chicken and egg' debate regarding the nature of the relationship between young people and authority. For example, research findings indicate that gang members endorse more anti-authority attitudes than their non-gang counterparts (Alleyne \& Wood, 2010; Kakar, 2005; Lurigio, Flexon, \& Greenleaf, 2008). This has been attributed to the nature of their gang identities. That is, gang membership comes with common attitudes and beliefs such as anti-authority attitudes regardless of actual contact with authority (Khoo \& Oakes, 2000). On the other hand, research findings have also indicated that negative and persistent contact with authority (possibly due to gang members engaging in illegal activity) reinforces gang identities (McAra \& McVie, 2005; Ralphs, Medina, \& Aldridge, 2009). These findings suggest a reciprocal relationship that denotes a status hierarchy.

Finally, specific socio-cognitive processes are needed to enable and sustain hierarchical distinctions and reinforce the motivation to achieve the higher status. For example, gang youth who commit criminal activities would arguably still be aware of the legal boundaries they are crossing but by using specific socio-cognitive processes they are able to re-frame their socialized moral standards to support their illegal conduct.

Criminologists describe a process by which gang members neutralize the perceived negative consequences of their illegal/criminal behavior (e.g. Esbensen \& Weerman, 2005; Melde \& Esbensen, 2011) rendering them guilt-free (Esbensen, Peterson, Taylor, \& Freng, 2009), by employing neutralization techniques (Sykes \& Matza, 1957). Bandura and colleagues (1996) re-conceptualized these techniques in the form of moral disengagement - the "cognitive 


\section{Running Head: STREET GANG MEMBERS IN CUSTODY}

restructuring of inhumane conduct into benign or worth behavior" (Bandura, 2002, p. 101) and found a link between moral disengagement and violent behavior.

Past research has found that gang members are more likely to endorse specific moral disengagement strategies, more so than their non-gang counterparts (Alleyne \& Wood, 2010). Research has also offered some evidence to support that within prison establishments prison inmates who engage in bullying are likely to morally disengage (South \& Wood, 2006; Wood, Moir, \& James, 2009), and more specifically, this was found in gang-involved prison inmates (Wood et al., 2009). This implies that moral disengagement has an integral role in group processes. Since youth crime is typically conducted in groups, it can be argued that group members encourage each other to morally disengage (Hakkert, van Wijk, Ferweda, \& Eijken, 2001), perhaps in the form of shared attitudes and beliefs (Akers, 1997). The literature also suggests that gangs provide an environment that fosters delinquency and violence through a process of facilitation (Hall, Thornberry, \& Lizotte, 2006; Lopez \& Emmer, 2002), creating yet another opportunity for group-based attitudes and processes to flourish.

\section{Our Study}

The current literature is scant on the psychological processes underlying gang involvement (Wood \& Alleyne, 2010). This study compared gang youth with non-gang youth on attitudes and beliefs associated with aggressive and violent behavior that reinforce status hierarchies within and between gangs. Although we presented some evidence from the existing literature that supports social dominance theory, this theory has not been empirically tested in the street gang context. To remedy this neglect this theory provided the basis for this study as it encompasses the intricacies of group process within the driving force of status acquisition. 
Running Head: STREET GANG MEMBERS IN CUSTODY

This study was conducted in a UK Young Offenders Institution (YOI), so comparisons were made between gang-involved offenders (i.e., offenders who were members of a street gang prior to their custodial sentence) and offenders who were not affiliated with street gangs but other types of potentially criminal groups, of which there are many (Klein \& Maxson, 2006; Sullivan, 2006). This study also had a secondary purpose - to evaluate differences amongst varying methods of identifying gang members. This is particularly important if gang members are to be targeted in custodial settings for specialist programmes. Based on previous findings and social dominance theory, we expected that gang members would be affiliated with groups who engaged in more criminal activity than non-gang offenders, and gang members would report higher levels of social dominance orientation, hypermasculine values, anti-authority attitudes and moral disengagement than non-gang offenders.

\section{Method}

\section{Participants}

Participants were recruited from a male young offender institution (YOI) by a research assistant $(N=188)$. The YOI, located in the UK, cares for approximately 400 juveniles between the ages of 16 and 18 years old. This YOI serves sentencing courts in many of the urban metropolitan cities (such as London, Birmingham, Bristol, etc.) and, therefore, houses young offenders from gang-affected communities. The mean age of the sample recruited was $16.88(S D=.57$, range $=16-18)$. The majority of participants indicated that they were White UK/Irish (58\%), and the remaining participants indicated that they were Black/Black British (24\%), Asian (5\%), Mixed Ethnicity (12\%), and Other (1\%). Since the majority of participants indicated that they were White UK/Irish, the sample was split into White (58\%) and Non-white (42\%) for analyses purposes below. The mean sentence length 
Running Head: STREET GANG MEMBERS IN CUSTODY

in months reported by the participants was $27.24(S D=39.73$, range $=0-300$; see Table 1$)$. Participants who reported a sentence length of 0 were on remand pending the outcome of their criminal trial.

Insert Table 1 about here

\section{Measures}

The Youth Survey: Eurogang Program of Research (Weerman et al., 2009). This is a comprehensive instrument consisting of 89 items including information on demographic characteristics. Since this measure was originally designed to be administered in schools, an additional item was added asking respondents to indicate the length of their custodial sentence. This instrument is also designed to identify those who do and do not belong to a gang, according to the Eurogang definition and contains further measures on antisocial behavior, risk and protective factors.

Gang Membership. Due to previous definitional debates in the literature (e.g., Klein \& Maxson, 2006; Matsuda, Esbensen, \& Carson, 2012) and the nature of this study's sample, gang membership was explored using varying methods of identification. Employing the Eurogang method, group affiliations were first assessed with the following item: "In addition to any such formal groups, some people have a certain group of friends that they spend time with, doing things together or just hanging out. Do you have a group of friends like that?" Participants who responded "yes" were then asked questions assessing gang membership. According to the Eurogang definition the following four components were measured: (1) youthfulness - all members of the group were under the age of 25 ; (2) durability - the group had been together for more than three months; (3) street-orientation - responding "yes" to the item "Does this group spend a lot of time together in public places like the park, the street, shopping areas, or the neighborhood?"; (4) group criminality as an integral part of the group 
Running Head: STREET GANG MEMBERS IN CUSTODY

identity - responding "yes" to the items "Is doing illegal things accepted by or okay for your group?" and "Do people in your group actually do illegal things together?". If participants met these criteria they were identified according to the Eurogang definition.

The self-nomination method was also employed where participants responded 'yes' to the item "Do you consider your group of friends to be a gang?" And finally, a third category of gang membership was characterized by participants who met all four criteria of the Eurogang definition and responded 'yes' to the self-nomination item. We acknowledge the issues that may arise when explicitly using the term 'gang' in research (see Esbensen, Winfree, He, \& Taylor, 2001; Esbensen \& Maxson, 2012, for review of literature), however, examining the self-identification method was particularly useful in this study in distinguishing gang members from offenders who claim membership to other types of antisocial groups.

Group Crime. Fourteen items were used to assess the extent participants' groups were involved in crime. Using a four-point Likert-type scale (ranging from 'never' to 'often'), they were asked how often their group committed a range of offences. Examples include: 'threaten people,' 'illegal drug use,' 'destroy property,' and 'physical assault.' Scores could range from 14 to 56 with higher scores on this scale indicating higher involvement in crime. This scale has previously demonstrated high internal consistency (e.g., Alleyne \& Wood, 2013; $\alpha=.89$ ), and this has been further substantiated in the current study $(\alpha=.91)$.

\section{Mechanisms of Moral Disengagement Scale (Bandura, Barbarnelli, Carpara, \&}

Pastorelli, 1996). Bandura et al.'s (1996) scale consists of 32 items assessing participants' endorsements of moral disengagement strategies. Participants responded on a five-point Likert-type scale ranging from 1 (strongly disagree) to 7 (strongly agree). The scale is further broken down into eight subscales (consisting of four items each) for each of the moral 


\section{Running Head: STREET GANG MEMBERS IN CUSTODY}

disengagement strategies. Examples of items include: "It is alright to beat up someone who bad mouths your family" (moral justification); "Slapping and shoving someone is just joking around" (euphemistic labelling); "Damaging some property is no big deal when you consider that others are beating people up" (advantageous comparison); "If kids are not disciplined they should not be blamed for misbehaving" (displacement of responsibility); "A person who only suggests breaking rules should not be blamed if others go ahead and do it" (diffusion of responsibility); “Teasing someone doesn't really hurt them” (distorting consequences); "If people are careless where they leave their things it is their own fault if they get stolen" "attribution of blame"; and "Someone who is horrible does not deserve to be treated like a human being" (dehumanization of victims). The range of scores for the overall scale is 32 to 224 and the range for each subscale is 4 to 28 . Higher responses on this scale (and its subscales) indicates a proneness to employ moral disengagement strategies. Bandura and colleagues (1996) reported the alpha coefficient for the composite measure to be .82 . We found a similarly high reliability coefficient $(\alpha=.87)$.

\section{The Hypermasculine Values Questionnaire-Short Version (Archer, 2010).}

Archer's (2010) 16-item scale measures hypermasculine attitudes and values. Participants responded on a seven-point Likert-type scale ranging from 1 (strongly disagree) to 7 (strongly agree) whereby higher scores indicated higher endorsements of hypermasculine values. Participants' scores could range from 16 to 112. Examples of items include: "Men who take part in yoga or ballet deserve to be ridiculed" and "Real men don't back away from barroom confrontations". Archer's (2010) original study reported a high internal consistency $(\alpha=.91)$ but the scale's alpha coefficient in our study indicated a poor internal consistency $(\alpha$ $=.59)$. 
Running Head: STREET GANG MEMBERS IN CUSTODY

The Social Dominance Orientation Scale (Sidanius \& Pratto, 1999). Sidanius and Pratto's (1999) measure assesses the extent to which respondents endorse hierarchical attitudes between groups. The scale consists of 16 items where participants responded on a seven-point Likert-type scale ranging from 1 (strongly disagree) to 7 (strongly agree). Participants' responses could range from 16 to 112. Examples include: "Some groups of people are simply inferior to other groups" and "To get ahead in life, it is sometimes necessary to step on other groups". Previous studies that have used this scale reported high reliability coefficients (e.g., >.89 - Henry, Sidanius, Levin, \& Pratto, 2005; >.81 - Pratto, Liu, Levin, Sidanius, Shih, Bachrach, \& Hegarty, 2000), and similarly, the scale demonstrated high internal consistency in our study $(\alpha=.81)$.

The Attitude Toward Formal Authority Scale (Reicher \& Emler, 1985). Reicher and Emler's (1985) 17 item scale assesses participants' attitudes toward authority figures (e.g., teachers, police, etc.). Participants responded on a seven-point Likert-type scale ranging from 1 (strongly disagree) to 7 (strongly agree) whereby higher scores indicated a more negative attitude towards authority (range 17-119). Example items include: "A lot of teachers care more about an easy life than about what happens to their pupils" and "The police pick on me and give me a bad time". Reicher and Emler (1985) reported an alpha score of .93 for their original scale. We found the measure to be a fairly reliable scale as well $(\alpha=.79)$.

\section{Procedure}

Prior to data collection, the study was approved by the School of Psychology's Ethics Committee. All available young offenders who met the inclusion criterion (i.e., 16 years and older) were asked by a research assistant to participate in this study. Participants were met by a research assistant individually in a private room where the purpose of the study and 


\section{Running Head: STREET GANG MEMBERS IN CUSTODY}

procedure were explained and an information sheet was given to them (or read to them if requested). Participants were instructed that the questionnaires evaluated the nature of their friendship groups. All participants were informed that participation was voluntary which meant they could leave the study at any time without penalty. Participants were informed that their responses were confidential. They were also informed that their responses would have a code, which would be given to them on their debrief sheet so that if they chose to withdraw, their data could be identified and destroyed. Following this briefing, participants were given the opportunity to leave the study if they wished to do so. Questionnaires were administered individually with a research assistant present to provide help if needed. Questionnaires took approximately 60 minutes to complete, after which participants were debriefed verbally and provided with a debriefing sheet which reiterated the purpose of the study, provided information on how to withdraw their data if they chose to do so, and offered the researchers' contact details should they have further questions.

\section{Results}

Data were entered into SPSS 20 where analyses were conducted using a $p<.05$ level of significance.

\section{Membership}

Participants were split into four groups based on the gang membership criteria described above. Of the 188 participants recruited for the current study, 73 (39\%) were identified as non-gang youth who did not meet any of the criteria; 31 (17\%) were selfidentified gang members but did not meet the Eurogang criteria; 61 (32\%) were gang members who met the Eurogang criteria but did not self-identify; and 23 (12\%) were selfidentified gang members who met the Eurogang criteria. Given the lack of prison-based gang 
Running Head: STREET GANG MEMBERS IN CUSTODY

research in the UK, comparisons on gang prevalence are limited. The proportion of gang members identified in this sample is the highest reported in the UK (e.g., school-based sample, 7\% current membership, Alleyne \& Wood, 2010; arrestee sample, 4-11\% current and past membership, Bennett \& Holloway, 2004). Since this sample was recruited from a YOI, the higher prevalence was expected due to the younger age demographic and their convictions for criminal behavior.

\section{Demographic Characteristics}

Using a oneway ANOVA, we found no significant differences between the four groups on age $\left(F(3,184)=.05, p=.985, \eta^{2}=.0008\right)$ and sentence length $(F(3,183)=1.18, p$ $=.319, \eta^{2}=.02$ ). We also found no significant differences between the four groups on ethnicity $\left(\chi^{2}(12, N=188)=6.99, p=.858\right.$, Cramer's V $\left.=.11\right)$. See Table 1 for means and frequencies.

\section{Reasons for Joining the Street Gang}

The Eurogang Youth Survey (Weerman et al., 2009) contains items asking participants to indicate the reasons for joining their chosen group (either gang or non-gang). We conducted chi-square inferential tests to see whether there were significant differences between groups on their endorsed reasons for joining their group (arguably their street gang). There were significant differences for the following reasons: to prepare for the future, for protection, to get away with illegal activities, to participate in group activities, to claim a specific territory, to get money or other possessions, to get money from selling drugs, and a friend belonged to the group. For all of these reasons the self-identified gang members fitting the Eurogang criteria had the highest proportion of endorsements with the exception of joining because a friend belonged (self-identified gang members not fitting the Eurogang 
Running Head: STREET GANG MEMBERS IN CUSTODY

criteria had the highest proportion). The non-gang youth had the lowest proportion of endorsements except for the reason 'to participate in group activities' where gang members fitting the Eurogang criteria had the lowest proportion (see Table 2 for frequencies and chisquare statistics).

Insert Table 2 about here

\section{Group Crimes}

We conducted a oneway ANOVA to see whether each type of group crime varied as a function of group membership. There were significant differences for all of the group crimes except for graffiti and illegal alcohol use (see Table 3 for means, standard deviations, and ANOVA statistics). Follow-up tests were conducted to evaluate the nature of the differences between groups. Non-gang youth had the lowest mean scores for all of the group crimes. The Bonferroni post hoc analysis showed that the self-identified gang members not fitting the Eurogang criteria scored significantly higher than non-gang youth on threatening people, fighting, theft, selling protection, robbery, selling drugs, carrying weapons, destroying property, physical assault, and breaking and entering. The gang members fitting the Eurogang criteria scored significantly higher than non-gang youth on threatening people, fighting, and theft. Finally, the self-identified gang members who also fit the Eurogang criteria group scored significantly higher than non-gang youth on threatening people, fighting, robbery, selling drugs, carrying weapons, and physical assault. The post hoc analysis did not reveal the group differences for stealing cars and illegal drug use although there was an overall significant effect.

\section{Psychological and Behavioral Characteristics}


Running Head: STREET GANG MEMBERS IN CUSTODY

We conducted a MANOVA to compare the groups on psychological (i.e., eight moral disengagement strategies, anti-authority attitudes, hypermasculinity, and social dominance orientation) and behavioral (i.e., group crime) measures (see Table 4 for means, standard deviations, and MANOVA statistics). Given the unequal $n$ s across the four groups, we first checked the homogeneity of covariance matrices and found that they were indeed homogeneous $(p=.604)$ ensuring that our assessment of power would be accurate. The MANOVA revealed an overall significant effect, $F(36,512)=2.09, p<.001$; Pillai's Trace $=$ $.298 ; \eta_{p}{ }^{2}=.13$. When examining the univariate tests we found significant differences for euphemistic labelling, displacement of responsibility, dehumanization, anti-authority attitudes, hypermasculinity, social dominance orientation, and group crime. The Bonferroni post hoc analysis revealed a much more complex pattern of responding. The self-identified gang members scored significantly higher than non-gang youth on two measures, social dominance orientation and group crime. The gang members fitting the Eurogang criteria (but not self-identified) scored significantly lower than the self-identified gang members fitting the Eurogang criteria group on euphemistic labelling and displacement of responsibility, and they scored significantly lower than the self-identified gang members not fitting the Eurogang definition on group crime. Finally, the self-identified gang members fitting the Eurogang criteria scored significantly higher than non-gang youth on euphemistic labelling, displacement of responsibility, hypermasculinity, and group crime. The post hoc analysis did not reveal group differences for dehumanization and anti-authority attitudes.

Insert Table 4 about here

\section{Additional Analyses}

We also conducted a discriminant function analysis to determine which of the variables listed above best discriminated the four groups. Three discriminant functions were 


\section{Running Head: STREET GANG MEMBERS IN CUSTODY}

calculated. The first function explained $65.3 \%$ of the variance (canonical $R^{2}=.23$ ), the second function explained $19.7 \%$ of the variance (canonical $R^{2}=.08$ ), and the third function explained $15.0 \%$ of the variance (canonical $R^{2}=.06$ ). The first function, a combination of all three, was significant in differentiating the four groups, $\Lambda=.67, \chi^{2}(36)=72.54, p<.001$. Neither of the remaining functions were significant $\left(\Lambda=.86, \chi^{2}(22)=26.72, p=.222\right.$ and $\Lambda$ $=.94, \chi^{2}(10)=11.61, p=.312$, respectively). In descending order of correlations with the discriminant function, group crime, social dominance orientation, displacement of responsibility, anti-authority attitudes, dehumanization, hypermasculinity, and euphemistic labelling were the best predictors of gang membership. See table 5 for discriminant function coefficients. Overall the discriminant function successfully classified $47 \%$ of cases.

\section{Insert Table 5 about here}

\section{Discussion}

The purpose of the current study was to use social dominance theory as an organizing concept to determine the psychological processes that could distinguish, at least in part, ganginvolved youth from a control group of non-gang offenders. We argued that street gang members were more likely than non-gang offenders to be affiliated with groups who commit more crime. It was also argued that group-based attitudes and beliefs such as social dominance orientation, hypermasculine values, moral disengagement, and anti-authority attitudes would be inherent in gang-involved youth and that these factors would distinguish gang-involved youth from non-gang youth in a YOI sample. We also explored differences amongst varying methods of identifying gang members. We found that participants in "gang" groups reported being affiliated with groups who engage in a variety of crimes more so than non-gang youth. We also found that group crime, social dominance orientation, anti-authority attitudes, hypermasculinity, and the moral disengagement strategies euphemistic labelling, 


\section{Running Head: STREET GANG MEMBERS IN CUSTODY}

displacement of responsibility, and dehumanization were important variables in distinguishing group membership.

First, we found that the reasons for joining a group endorsed more by gang-involved youth than non-gang offenders were: to prepare for the future, for protection, to get away with illegal activities, to claim a specific territory, to get money or other possessions, to get money from selling drugs, and a friend belonged to the group. The self-identified gang members fitting the Eurogang definition had the highest proportion of endorsements bar one reason, joining because a friend belonged (self-identified gang members not fitting the Eurogang criteria had the highest proportion). These reasons for joining a group, according to social dominance theory, demonstrate a process of implementing a status hierarchy. For example, youth who become involved in gangs may be those who perceive more threat from others (Decker, 1996; Decker \& Van Winkle, 1996). Also, it is not surprising that these young people join gangs where they already know members of the gang. This supports the process of identifying with the ingroup whereby the determinants of social identity within a framework of a group include: ingroup-outgroup distinctions (e.g., favoritism vs. discrimination), shared attitudes, values, and beliefs (Goldstein, 2002). The identification with an ingroup in conjunction with the motivation to acquire status was also illustrated by respondents indicating that they wanted a territory to claim as their own and earn money (even if it is illegitimately). This has also been seen at varying levels of membership in past literature (e.g., Alleyne \& Wood, 2010).

When examining specific group crimes we found, as expected, the groups ganginvolved youth were affiliated with engaged in significantly more aggressive and violent crimes (i.e., threaten people, fight, sell illegal drugs, carry weapons, and physical assault). This finding fits with prior studies on gang members in custody (e.g., DeLisi, Berg, \& Hochstetler, 2004; Drury \& DeLisi, 2011). Also, this finding provides support that gang 
involvement facilitates criminal behavior over and above delinquent youth (Battin, Hill, Abbott, Catalano, \& Hawkins, 1998) regardless of how they are identified.

Many of the group crimes that gang-involved youth endorse can be argued to be a physical manifestation of their intent to achieve social dominance over outgroups. For example, threats can be used to intimidate others and past research has argued that gangs use forms of intimidation to protect their territory (Alleyne \& Wood, 2014; Spergel, 1995). The use of threats, in conjunction with the finding above - that some young people join gangs to claim a specific territory - offers empirical support for this argument. The use of physical violence is another form of intimidation to achieve social dominance over outgroups. This finding has been supported by much of the gang literature (e.g., Decker \& Van Winkle, 1996; Klein \& Maxson, 2006). We can also argue that the selling of drugs enables street gangs to compete within the drug market (Bennett \& Holloway, 2004; Taniguchi, Ratcliffe, \& Taylor, 2011; Tita \& Ridgeway, 2007) and the income generated from selling drugs can be an indicator of status for the gang itself. Lastly, overall group crime contributed the most in distinguishing the four groups of offenders (i.e., non-gang youth, self-identified gang members not fitting the Eurogang criteria, gang members fitting the Eurogang definition but not self-identified, and self-identified gang members fitting the Eurogang definition). This finding ties in with previous gang research that showed that once in a gang, members become far more delinquent than they were before (Thornberry, Krohn, Lizotte, Smith, \& Tobin, 2003), even if they associated with prolifically offending peers (Klein, Weerman, \& Thornberry, 2006), and when compared to non-gang offenders (Drury \& DeLisi, 2011).

When we examined psychological and behavioral characteristics we found that the gang members fitting the Eurogang definition (but not self-identified) did not differ from non-gang offenders on any of the measures. Self-identified gang members who did not meet the Eurogang criteria scored significantly higher than non-gang youth on social dominance 


\section{Running Head: STREET GANG MEMBERS IN CUSTODY}

orientation whereas self-identified gang members who did meet the Eurogang criteria scored significantly higher than non-gang youth on euphemistic labelling, displacement of responsibility, and hypermasculine values. These findings, in conjunction with the above reasons for joining and specific group crimes committed, highlight group processes that are inherently driven by aspirations for social dominance. For example, this is exemplified by gang members' use of the 'displacement of responsibility' mechanism. Alleyne and Wood (2010) argued that lower ranked members of a gang, in particular, would employ this mechanism and that this allowed them to engage in violent behavior probably to prove themselves worthy of climbing the ranks of their gang. These behaviors and their use of language (i.e., euphemisms) could be mimicked from what they perceive as acceptable gang behavior (Hughes \& Short, 2005; Przemieniecki, 2005).

Hypermasculine values were endorsed more by self-identified gang members fitting the Eurogang critieria than by non-gang youth. These attitudes were also important in distinguishing the gang members. These values indicate a perceived gender-based hierarchy whereby hypermasculine values (i.e., attitudes and beliefs that support aggressive behavior and devalue female roles) legitimize gang-related violence in order to distinguish one street gang as higher status than another. Lopez and Emmer (2002) found this link in their study. The current study not only supports this finding but it also expands on it by showing that there is a distinct difference between levels of hypermasculinity in street gang members and non-gang offenders. In addition, these shared hypermasculine values, in conjunction with gang members' endorsement of dehumanization and displacement of responsibility strategies, further exemplify the level of ingroup cohesion and the establishment of a social identity (Goldstein, 2002). Our findings also support that gang members perceive a hierarchy more so than non-gang offenders based on their responses indicating a social dominance orientation (i.e., the degree to which we endorse hierarchical distinctions; Sidanius \& Pratto, 1999). And 


\section{Running Head: STREET GANG MEMBERS IN CUSTODY}

it is important to note that the hierarchy may not only be perceived amongst other offenders, but also gang members' endorsement of anti-authority attitudes suggests that they make ingroup-outgroup distinctions with persons of authority (e.g., prison officers). Past literature has shown that negative contact experiences between gang members and authority figures further reinforce gang identities (Khoo \& Oakes, 2000; McAra \& McVie, 2005; Ralphs et al., 2009).

There are some caveats to acknowledge when considering the above findings. This study was conducted in the UK and thus the findings may not be applicable to street gangs in other countries. However, given that the psychological factors identified in the current study are likely to be universal psychological mechanisms, there is a strong chance that the current findings will be as applicable to other countries as they are to the UK. This can only be verified with future cross-cultural research.

There are interesting inferences to be made from our data, but it must be noted that the research design was cross-sectional. Therefore, we cannot say for certain whether the psychological and behavioral characteristics that clearly distinguish gang members from nongang offenders were present before gang membership or resulted from gang membership. For example, Thornberry et al. (2003) clearly outlines three processes whereby young people may join gangs: selection where gangs select and recruit members who are already delinquent (Lahey, Gordon, Loeber, Stouthamer-Loeber, \& Farrington, 1999; Craig, Vitaro, Gagnon, \& Trembley, 2002); facilitation where gangs provide opportunities for delinquency to youth who were not delinquent beforehand (Gatti, Tremblay, Vitaro, \& McDuff, 2005; Gordon et al., 2004; Thornberry, Krohn, Lizotte, \& Chard-Wiershem, 1993); and enhancement where gang members are recruited from a population of high-risk youth who, as gang members, become more delinquent (Gatti et al., 2005; Thornberry et al., 1993). So it is not clear if the gang members were recruited into the gang because they already exhibited the key 


\section{Running Head: STREET GANG MEMBERS IN CUSTODY}

characteristics found in this study or they developed these characteristics once in the gang. Lastly, the data collected in this study were solely from self-reports, which could have resulted in our findings having been biased by common method variance. However, for the purpose of assessing the respondents' perceptual and experiential constructs, not to mention the sensitive nature of some of the items and the YOI environment where data collection occurred, self-report was deemed to be the most fruitful method (see Chan, 2009).

The examination of psychological factors that feed into gang membership has significant importance when developing treatment strategies for gang-affiliated offenders in custodial settings. Individual differences variables such as anger management, empathy, poor compliance, and attention deficit hyperactivity disorder have not been found to differentiate gang-involved offenders from non-gang offenders (Chu et al., 2011). Many of the treatment programs available to offenders in custody incorporate training in anger management, problem solving skills and coping skills (to name a few) to address a variety of treatment needs (Hollin, Browne, \& Palmer (2002). However, the current study and other recent findings (e.g., Scott, 2014) highlight areas that distinguish gang members from other types of offenders, thus indicating additional needs that should be addressed in treatment. For example, gang membership is accompanied by an array of intra- and inter-group processes that do not only facilitate behavior amongst young people but also have implications for their interactions with persons of authority. This study also highlights definitional issues that need further consideration in custodial settings, especially if targeting gang-affiliated youth for specialized treatment. There needs to be further work examining the presence of psychopathologies and other psychological characteristics that may exacerbate gang culture and gang-related violence. 
Running Head: STREET GANG MEMBERS IN CUSTODY

\section{References}

Akers, R.L. (1997). Criminological theories: Introduction and evaluation ( $2^{\text {nd }}$ ed.). Los Angeles, USA: Roxbury.

Alleyne, E., \& Wood, J.L. (2010). Gang involvement: Psychological and behavioral characteristics of gang members, peripheral youth and non-gang youth. Aggressive Behavior, 36, 423-436. DOI: 10.1002/ab.20360

Alleyne, E., \& Wood, J.L. (2013). Gang-related crime: The social, psychological and behavioral correlates. Psychology, Crime, \& Law, 19, 611-627. DOI: 10.1080/1068316X.2012.658050

Alleyne, E., \& Wood, J.L. (2014). Gang involvement: Social and environmental factors. Crime \& Delinquency, 60, 547-568. DOI: 10.1177/0011128711398029

Anderson, E. (1999). Code of the street: Decency, violence and the moral life of the inner city. New York, NY: Norton and Company.

Archer, J. (2010). Derivation and assessment of a hypermasculine values questionnaire. British Journal of Social Psychology, 49, 525-551. DOI: 10.1348/014466609X471525

Bandura, A. (2002). Selective moral disengagement in the exercise of moral agency. Journal of Moral Education, 31, 101-119. DOI: 10.1080/0305724022014322

Bandura, A., Barbaranelli, C., Caprara, G. V., \& Pastorelli, C. (1996). Mechanisms of moral disengagement in the exercise of moral agency. Journal of Personality and Social Psychology, 71, 364-374. DOI: 10.1037/0022-3514.71.2.364

Battin, S. R., Hill, K. G., Abbott, R. D., Catalano, R. F., \& Hawkins, J. D. (1998). The contribution of gang membership to delinquency beyond delinquent friends. Criminology, 36, 93-115. DOI: 10.1111/j.1745-9145.1998.tb01241.x

Bennett, T., \& Holloway, K. (2004). Gang membership, drugs and crime in the UK. British Journal of Criminology, 44, 305-323. DOI: 10.1093/bjc/azh025 
Running Head: STREET GANG MEMBERS IN CUSTODY

Burk, L.R., Burkhart, B.R., \& Sikorski, J.F. (2004). Construction and preliminary validation of the Auburn Differential Masculinity Inventory. Psychology of Men \& Masculinity, 5, 4-17. DOI: 10.1037/1524-9220.5.1.4

Chan, D. (2009). So why ask me? Are self-report data really that bad? In C. E. Lance \& R. J. Vandenberg (Eds.), Statistical and methodological myths and urban legends: Doctrine, verity and fable in the organizational and social sciences (pp. 309-336). Hove, East Sussex, UK: Routledge, Taylor \& Francis Group.

Chu, C.M., Daffern, M., Thomas, S., \& Lim, J.Y. (2012). Violence risk and gang affiliation in youth offenders: A recidivism study. Psychology, Crime, \& Law, 18, 299-315. DOI: $10.1080 / 1068316 X .2010 .481626$

Craig, W.M., Vitaro, F., Gagnon, C., \& Tremblay, R.E. (2002). The road to gang membership: Characteristics of male gang and non-gang members from ages 10 to 14 . Social Development, 11, 53-68. DOI: 10.1111/1467-9507.00186

Decker, S. (1996). Collective and normative features of gang violence. Justice Quartery, 13, 243-264. DOI: 10.1080/07418829600092931

Decker, S. H., \& Van Winkle, B. (1996). Life in the gang: Family, friends, and violence. New York: Cambridge University Press.

DeLisi, M., Berg, M.T., \& Hochstetler, A. (2004). Gang members, career criminals and prison violence: Further specification of the importation model of inmate behavior. Criminal Justice Studies, 17, 369-383. DOI: 10.1080/1478601042000314883

Drury, A.J., \& DeLisi, M. (2011). Gangkill: An exploratory empirical assessment of gang membership, homicide offending, and prison misconduct. Crime \& Delinquency, 57, 130-146. DOI: $10.1177 / 0011128708325051$

Esbensen, F-A. \& Maxson, C.L. (Eds.). (2012). Youth gangs in international perspective. New York, NY: Springer. 
Running Head: STREET GANG MEMBERS IN CUSTODY

Esbensen, F-A., Peterson, D., Taylor, T.J., Freng, A. (2009). Similarities and differences in risk factors for violent offending and gang membership. Australian and New Zealand Journal of Criminology, 42, 310-335. DOI: 10.1375/acri.42.3.310

Esbensen, F-A., \& Weerman, F.M. (2005). Youth gangs and troublesome youth groups in the United States and the Netherlands: A cross-national comparison. European Journal of Criminology, 2, 5-37. DOI: 10.1177/1477370805048626

Esbensen, F-A., Winfree, L. T., Jr., He, N., \& Taylor, T. J. (2001). Youth gangs and definitional issues: When is a gang a gang, and why does it matter? Crime and Delinquency, 47, 105-130. DOI: 10.1177/0011128701047001005

Gatti, U., Haymoz, S., \& Schadee, H.M.A. (2011). Deviant youth groups in 30 countries: Results from the second international self-report delinquency study. International Criminal Justice Review, 21, 208-224. DOI: 10.1177/1057567711418500

Gatti, E., Tremblay, R. E., Vitaro, F., \& McDuff, P. (2005). Youth gangs, delinquency and drug use: a test of the selection, facilitation, and enhancement hypotheses. Journal of Child Psychology and Psychiatry, 46, 1178-1190. DOI: 10.1111/j.14697610.2005.00423.x

Goldstein, A. P. (2002). The psychology of group aggression. West Sussex, UK: John Wiley \& Sons Ltd.

Gordon, R. A., Lahey, B. B., Kawai, E., Loeber, R., Stouthamer-Loeber, M., \& Farrington, D. P. (2004). Antisocial behavior and youth gang membership: Selection and socialization. Criminology, 42, 55-87. DOI: 10.1111/j.1745-9125.2004.tb00513.x

Hagedorn, J. M. (2005). The global impact of gangs. Journal of Contemporary Criminal Justice, 21, 153-169. DOI: 10.1177/1043986204273390

Hakkert, A., van Wijk, A., Ferweda, H., \& Eijken, T. (2001). Group criminality. In M. W. Klein, H-J. Kerner, C. L. Maxson, \& E. G. M. Weitekamp (Eds.), The Eurogang 
Running Head: STREET GANG MEMBERS IN CUSTODY

Paradox: Street gangs and youth groups in the U.S. and Europe (pp. 221-229). Dordrecht: Kluwer Academic Press.

Hall, G. P., Thornberry, T. P., \& Lizotte, A. J. (2006). The gang facilitation effect and neighbourhood risk: Do gangs have a stronger influence on delinquency in disadvantaged areas? In J. F. Short, \& L. A. Hughes (Eds.), Studying youth gangs (pp. 47-61). Oxford, UK: Altamira Press.

Hannan, K.E., \& Burkhart, B.R. (1993). The topography of violence in college men: Frequency and comorbidity of sexual and physical aggression. Journal of College Student Psychotherapy, 8, 219-237. DOI: 10.1300/J035v08n03_02

Henry, P.J., Sidanius, J., Levin, S., \& Pratto, F. (2005). Social dominance orientation, authoritarianism, and support for intergroup violence between the Middle East and America. Political Psychology, 26, 569-583. DOI: 10.1111/j.1467-9221.2005.00432.x

Hollin, C. R., Browne, D., \& Palmer, E. J. (2002). Delinquency and young offenders. Oxford, UK: Blackwell Publishing.

Hughes, L. A., \& Short, J. F., Jr. (2005). Disputes involving youth street gang members: Micro-social contexts. Criminology, 43, 43-76. DOI: 10.1111/j.00111348.2005.00002.x

Kakar, S. (2005). Gang membership, delinquent friends and criminal family members: Determining the connections. Journal of Gang Research, 13(1), 41-52.

Khoo, A.C.E., \& Oakes, P.J. (2000). The variability of the delinquent self: Anti-authority attitudes and endorsement of neutralization techniques among incarcerated delinquents in Singapore. Asian Journal of Social Psychology, 3, 125-132. DOI: 10.1111/1467839X.00058

Klein, M. W., \& Maxson, C. L. (2006). Street gang patterns and policies. New York, NY: Oxford University Press, Inc. 
Running Head: STREET GANG MEMBERS IN CUSTODY

Klein, M. W., Weerman, F. M., \& Thornberry, T. P. (2006). Street gang violence in Europe. European Journal of Criminology, 3, 413-437. DOI: 10.1177/1477370806067911

Lahey, B.B., Gordon, R.A., Loeber, R., Stouthamer-Loeber, M., \& Farrington, D.P. (1999). Boys who join gangs: A prospective study of predictors of first gang entry. Journal of Abnormal Child Psychology, 27, 261-276. DOI:

10.1023/B:JACP.0000039775.83318.57

Lopez, V.A., \& Emmer, E.T. (2002). Influences of beliefs and values on male adolescents' decision to commit violent offenses. Psychology of Men \& Masculinity, 3, 28-40. DOI: $10.1037 / / 1524-9220.3 .1 .28$

Lurigio, A.J., Flexon, J.L., \& Greenleaf, R.G. (2008). Antecedents to gang membership: Attachments, beliefs, and street encounters with the police. Journal of Gang Research, $15(4), 15-33$.

Matsuda, K.N., Esbensen, F-A., \& Carson, D. (2012). Putting the "Gang” in "Eurogang": Characteristics of delinquent youth groups by different definitional approaches. In F-A. Esbensen, \& C.L. Maxson (Eds.), Youth gangs in international perspective: Results from the Eurogang Program of research (pp. 17-33). New York, NY: Springer.

McAra, L., \& McVie, S. (2005). The usual suspects?: Street-life, young people and the police. Criminology \& Criminal Justice, 5, 5-36. DOI: 10.1177/1466802505050977

Melde, C., \& Esbensen, F-A. (2011). Gang membership as a turning point in the life course. Criminology, 49, 513-552. DOI: 10.1111/j.1745-9125.2011.00227

Pratto, F., Liu, J.H., Levin, S., Sidanius, J., Shih, M., Bachrach, H., \& Hegarty, P. (2000). Social dominance orientation and the legitimization of inequality across cultures. Journal of Cross-Cultural Psychology, 31, 369-409. DOI:

$10.1177 / 0022022100031003005$ 
Running Head: STREET GANG MEMBERS IN CUSTODY

Przemieniecki, C. J. (2005). Gang behavior and movies: Do Hollywood gang films influence violent gang behavior? Journal of Gang Research, 12, 41-71.

Pyrooz, D.C., \& Decker, S.C. (2013). Delinquent behavior, violence, and gang involvement in China. Journal of Quantitative Criminology, 29, 251-272. DOI: 10.1007/s10940$012-9178-6$

Ralphs, R., Medina, J., \& Aldridge, J. (2009). Who needs enemies with friends like these? The importance of place for young people living in known gang areas. Journal of Youth Studies, 12, 483-500. DOI: 10.1080/13676260903083356

Reicher, S., \& Emler, N. (1985). Delinquent behavior and attitudes to formal authority. British Journal of Social Psychology, 24, 161-168. DOI: 10.1111/j.20448309.1985.tb00677.x

Scott, D.W. (2014). Attitude is everything: Youth attitudes, gang involvement, and length of institutional gang membership. Group Processes and Intergroup Relations. DOI: $10.1177 / 1368430214548285$

Short, J.F., Jr., \& Strodtbeck, F.L. (1965). Group process and gang delinquency. Chicago, IL: University of Chicago.

Shropshire, S., \& McFarquhar, M. (2002). Developing multi-agency strategies to address the street gang culture and reduce gun violence among young people. Briefing No. 4, Manchester: Steve Shropshire and Michael McFarquhar Consultancy Group.

Sidanius, J., \& Pratto, F. (1999). Social dominance. Cambridge, UK: Cambridge University Press.

South, R., \& Wood, J. (2006). Bullying in prisons: The importance of perceived social status, prisonization and moral disengagement. Aggressive Behavior, 32, 490-501. DOI: 10.1002/ab.20149

Spergel, I. A. (1995). The youth gang problem. NY: Oxford. 
Running Head: STREET GANG MEMBERS IN CUSTODY

Sullivan, M. L. (2006). Are "gang" studies dangerous? Youth violence, local context, and the problem of reification. In J. F. Short, \& L. A. Hughes (Eds.), Studying youth gangs (pp. 15-35). Oxford, UK: Altamira Press.

Sykes, G., \& Matza, D. (1957). Techniques of neutralization: A theory of delinquency. American Sociological Review, 22, 664-670. DOI: 10.2307/2089195

Tajfel, H., \& Turner, J. C. (1979). An integrative theory of social conflict. In W. Austin, \& S. Worchel (Eds.), The social psychology of intergroup relations (pp. 33-48). Monterey, CA: Brooks/Cole.

Taniguchi, T.A., Ratcliffe, J.H., \& Taylor, R.B. (2011). Gang set space, drug markets, and crime around drug corners in Camden. Journal of Research in Crime and Delinquency, 48, 327-363. DOI: 10.1177/0022427810393016

Thornberry, T. P., Krohn, M. D., Lizotte, A. J., Chard-Wierschem, D. (1993). The role of juvenile gangs in facilitating delinquent behavior. Journal of Research in Crime and Delinquency, 30, 55-87. DOI: 10.1177/0022427893030001005

Thornberry, T. P., Krohn, M. D., Lizotte, A. J., Smith, C., \& Tobin, K. (2003). Gangs and delinquency in developmental perspective. Cambridge: Cambridge University Press.

Tita, G., \& Ridgeway, G. (2007). The impact of gang formation on local patterns of crime. Journal of Research in Crime and Delinquency, 44, 208-237. DOI:

$10.1177 / 0022427806298356$

Vigil, D.V. (1988). Barrio gangs: Street life and identity in Southern California. Austin, TX: University of Texas Press.

Viki, G.T., \& Abrams, D. (2013). The social influence of groups on individuals. In F-A. Esbensen, \& C.L. Maxson (Eds.), Youth gangs in international perspective: Results from the Eurogang Program of research (pp. 3-33). New York, NY: Springer. 
Running Head: STREET GANG MEMBERS IN CUSTODY

Weerman, F. M., Maxson, C. L., Esbensen, F., Aldridge, J., Medina, J., \& van Gemert, F., (2009), Eurogang program manual background, development, and use of the Eurogang instruments in multi-site, multi-method comparative research. Retrieved from the Eurogang Network website:

http://www.umsl.edu/ ccj/eurogang/Eurogang_20Manual.pdf

White, R. (2006). Youth gang research in Australia. In J.F. Short, Jr., \& L.A., Hughes (Eds.), Studying youth gangs (pp. 161-179). Oxford, UK: Altamira Press.

Wood, J., Moir, A., \& James, M. (2009). Prisoners' gang-related activity: The importance of bullying and moral disengagement. Psychology, Crime, and Law, 15, 569-581. DOI: $10.1080 / 10683160802427786$

Wood, J.L., \& Alleyne, E. (2010). Street gang theory and research: Where are we now and where do we go from here? Aggression and Violent Behavior, 15, 100-111. DOI: 10.1016/j.avb.2009.08.005

Wood, J.L., \& Alleyne, E. (2012). Street gangs: A review of the inter- and intra-group processes. In J.L. Wood \& T.A. Gannon (Eds.), Group influence: Criminal activity and crime reduction. Willan. 
Running Head: STREET GANG MEMBERS IN CUSTODY

Table 1. Demographic characteristics of the total sample, non-gang youth, SI members, EG members, and SI+EG members

\begin{tabular}{lccccc}
\hline Demographic characteristics & Total & Non-gang & SI & EG & SI+EG \\
\hline Sample size (\%) & 188 & $73(39)$ & $31(17)$ & $61(32)$ & $23(12)$ \\
Mean age (SD) & 16.88 & 16.86 & 16.87 & 16.89 & 16.91 \\
& $(.57)$ & $(.58)$ & $(.67)$ & $(.52)$ & $(.51)$ \\
Ethnicity (\%) & $109(58)$ & $44(60)$ & $17(55)$ & $38(62)$ & $10(44)$ \\
White UK/Irish & $45(24)$ & $19(26)$ & $7(23)$ & $12(20)$ & $7(30)$ \\
Black/Black British & $9(5)$ & $3(4)$ & $2(6)$ & $2(3)$ & $2(9)$ \\
Asian & $23(12)$ & $7(10)$ & $4(13)$ & $8(13)$ & $4(17)$ \\
Mixed & $2(1)$ & 0 & $1(3)$ & $1(2)$ & 0 \\
Other & 27.24 & 33.47 & 18.77 & 25.52 & 23.39 \\
Sentence length (SD) & $(39.73)$ & $(52.77)$ & $(15.48)$ & $(34.02)$ & $(23.32)$
\end{tabular}

SI = self-identified gang members not fitting the Eurogang definition; EG = gang members fitting the Eurogang definition but not self-identified; SI+EG = self-identified gang members fitting the Eurogang definition. 
Running Head: STREET GANG MEMBERS IN CUSTODY

Table 2. Proportion of responses endorsing reasons for joining groups across non-gang youth, SI members, EG members, and SI+EG members

\begin{tabular}{|c|c|c|c|c|c|c|}
\hline Variable & $\begin{array}{c}\text { Non-gang } \\
n(\%)\end{array}$ & $\begin{array}{c}\text { SI } \\
n(\%)\end{array}$ & $\begin{array}{c}\text { EG } \\
n(\%)\end{array}$ & $\begin{array}{l}\text { SI+EG } \\
n(\%)\end{array}$ & $\chi^{2}$ & $\begin{array}{c}\text { Cramer's } \\
\text { V }\end{array}$ \\
\hline To feel important & $8(11)$ & $6(19)$ & $11(18)$ & $5(22)$ & 2.40 & .11 \\
\hline To feel like you belong to something & $11(15)$ & $10(32)$ & $13(21)$ & $8(35)$ & 6.07 & .18 \\
\hline To keep out of trouble & $17(23)$ & $2(7)$ & $14(23)$ & $4(17)$ & 4.52 & .16 \\
\hline For protection & $21(29)$ & $16(52)$ & $19(31)$ & $12(52)$ & $8.15^{*}$ & .21 \\
\hline To share secrets & $13(18)$ & $4(13)$ & $11(18)$ & $2(9)$ & 1.50 & .09 \\
\hline To have a territory of your own & $18(25)$ & $19(61)$ & $21(34)$ & $16(70)$ & $22.74 * * *$ & .34 \\
\hline To get your parents' respect & $5(7)$ & $2(7)$ & $8(13)$ & $3(13)$ & 2.18 & .11 \\
\hline Because someone in your family was a member of the group & $9(12)$ & $8(26)$ & $6(10)$ & $6(26)$ & 6.56 & .19 \\
\hline To meet members of the opposite sex & $20(27)$ & $8(26)$ & $11(18)$ & $7(30)$ & 2.18 & .11 \\
\hline
\end{tabular}




\section{Running Head: STREET GANG MEMBERS IN CUSTODY}

\begin{tabular}{|c|c|c|c|c|c|c|}
\hline To get money or other things & $34(47)$ & $26(84)$ & $37(61)$ & $20(87)$ & $19.84 * * *$ & .33 \\
\hline To get money or other things from selling drugs & $31(43)$ & $24(77)$ & $30(49)$ & $21(91)$ & $24.62 * * *$ & .36 \\
\hline Because a friend was a member of the group & $25(34)$ & $20(65)$ & $25(41)$ & $13(57)$ & $9.79 *$ & .23 \\
\hline For company & $30(41)$ & $11(36)$ & $26(43)$ & $9(39)$ & 2.08 & .07 \\
\hline
\end{tabular}

$* p<.05 . * * p<.01 . * * * p<.001$.

SI = self-identified gang members not fitting the Eurogang definition; EG = gang members fitting the Eurogang definition but not self-identified;

$\mathrm{SI}+\mathrm{EG}=$ self-identified gang members fitting the Eurogang definition. 
Running Head: STREET GANG MEMBERS IN CUSTODY

Table 3. Means, standard deviations, and ANOVA statistics for group crimes

\begin{tabular}{|c|c|c|c|c|c|}
\hline Variables & $M$ & $S D$ & $F$ & $p$ & $\eta^{2}$ \\
\hline SI $(n=31)$ & $2.87_{\mathrm{b}}$ & 1.20 & & & \\
\hline $\mathrm{SI}+\mathrm{EG}(n=23)$ & $2.74_{b c}$ & 1.05 & & & \\
\hline Fight & & & 15.70 & $<.001$ & .20 \\
\hline Non-gang $(n=73)$ & $2.34_{a}$ & .85 & & & \\
\hline SI $(n=31)$ & $3.42_{b}$ & .72 & & & \\
\hline Theft & & & 8.14 & $<.001$ & .12 \\
\hline Non-gang $(n=73)$ & $1.88_{\mathrm{a}}$ & .96 & & & \\
\hline SI $(n=31)$ & $2.84_{b}$ & 1.16 & & & \\
\hline $\mathrm{EG}(n=61)$ & $2.57_{\mathrm{b}}$ & 1.10 & & & \\
\hline SI+EG $(n=23)$ & $2.43_{\mathrm{ab}}$ & 1.04 & & & \\
\hline Robbery & & & 6.55 & $<.001$ & .10 \\
\hline Non-gang $(n=73)$ & $1.70_{\mathrm{a}}$ & .98 & & & \\
\hline $\mathrm{SI}(n=31)$ & $2.65_{\mathrm{b}}$ & 1.31 & & & \\
\hline $\mathrm{EG}(n=61)$ & $2.15_{\mathrm{ab}}$ & 1.08 & & & \\
\hline $\mathrm{SI}+\mathrm{EG}(n=23)$ & $2.44_{b}$ & 1.20 & & & \\
\hline Steal cars & & & 2.72 & .046 & .04 \\
\hline Non-gang $(n=73)$ & 1.64 & 1.02 & & & \\
\hline $\mathrm{SI}(n=31)$ & 2.16 & 1.32 & & & \\
\hline $\mathrm{EG}(n=61)$ & 2.11 & 1.21 & & & \\
\hline
\end{tabular}


Running Head: STREET GANG MEMBERS IN CUSTODY

\begin{tabular}{|c|c|c|c|c|c|}
\hline SI+EG $(n=23)$ & 2.13 & 1.06 & & & \\
\hline Sell drugs & & & 8.45 & $<.001$ & .12 \\
\hline SI $(n=31)$ & $3.45_{\mathrm{bc}}^{\mathrm{a}}$ & 1.03 & & & \\
\hline $\mathrm{SI}+\mathrm{EG}(n=23)$ & $3.70_{\mathrm{b}}$ & .88 & & & \\
\hline Carry weapon & & & 11.82 & $<.001$ & .16 \\
\hline Non-gang $(n=73)$ & $2.14_{a}$ & 1.17 & & & \\
\hline Destroy property & & & 4.54 & .004 & .07 \\
\hline Non-gang $(n=73)$ & $1.58 \mathrm{a}$ & .86 & & & \\
\hline $\mathrm{SI}(n=31)$ & $2.32_{\mathrm{b}}$ & 1.17 & & & \\
\hline $\mathrm{EG}(n=61)$ & $1.85_{\mathrm{ab}}$ & 1.00 & & & \\
\hline $\mathrm{SI}+\mathrm{EG}(n=23)$ & $1.83_{\mathrm{ab}}$ & .72 & & & \\
\hline Graffiti & & & 2.11 & .101 & .03 \\
\hline Non-gang $(n=73)$ & 1.27 & .69 & & & \\
\hline $\mathrm{SI}(n=31)$ & 1.71 & 1.10 & & & \\
\hline $\mathrm{EG}(n=61)$ & 1.39 & .86 & & & \\
\hline $\mathrm{SI}+\mathrm{EG}(n=23)$ & 1.52 & .79 & & & \\
\hline Illegal drug use & & & 3.14 & .027 & .05 \\
\hline Non-gang $(n=73)$ & 2.75 & 1.26 & & & \\
\hline $\operatorname{SI}(n=31)$ & 3.39 & 1.02 & & & \\
\hline $\mathrm{EG}(n=61)$ & 3.00 & 1.25 & & & \\
\hline SI+EG $(n=23)$ & 3.43 & .99 & & & \\
\hline Illegal alcohol use & & & .96 & .411 & .02 \\
\hline
\end{tabular}


Running Head: STREET GANG MEMBERS IN CUSTODY

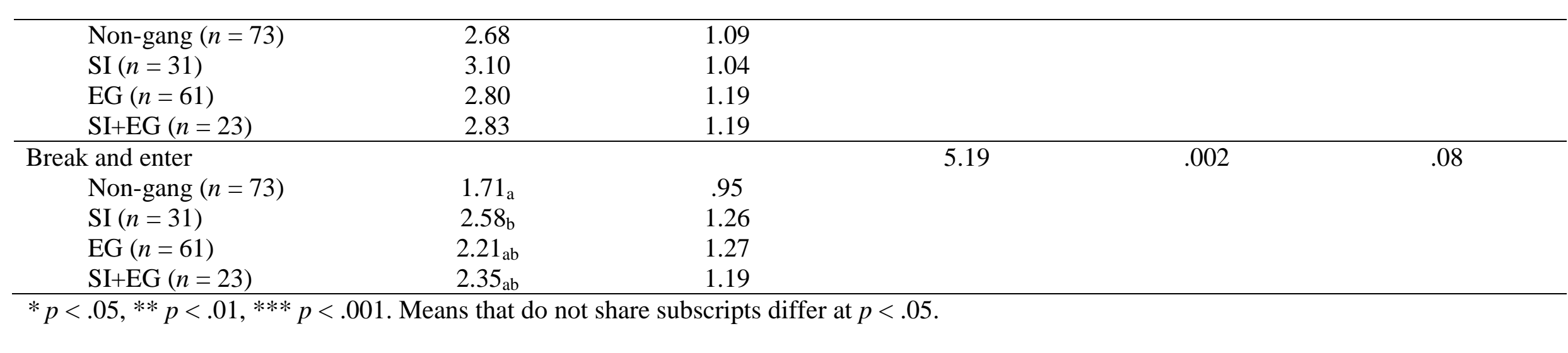

SI = self-identified gang members not fitting the Eurogang definition; EG = gang members fitting the Eurogang definition but not self-identified;

SI+EG $=$ self-identified gang members fitting the Eurogang definition. 
Running Head: STREET GANG MEMBERS IN CUSTODY

Table 4. Means, standard deviations, and MANOVA statistics for psychological and behavioral measures

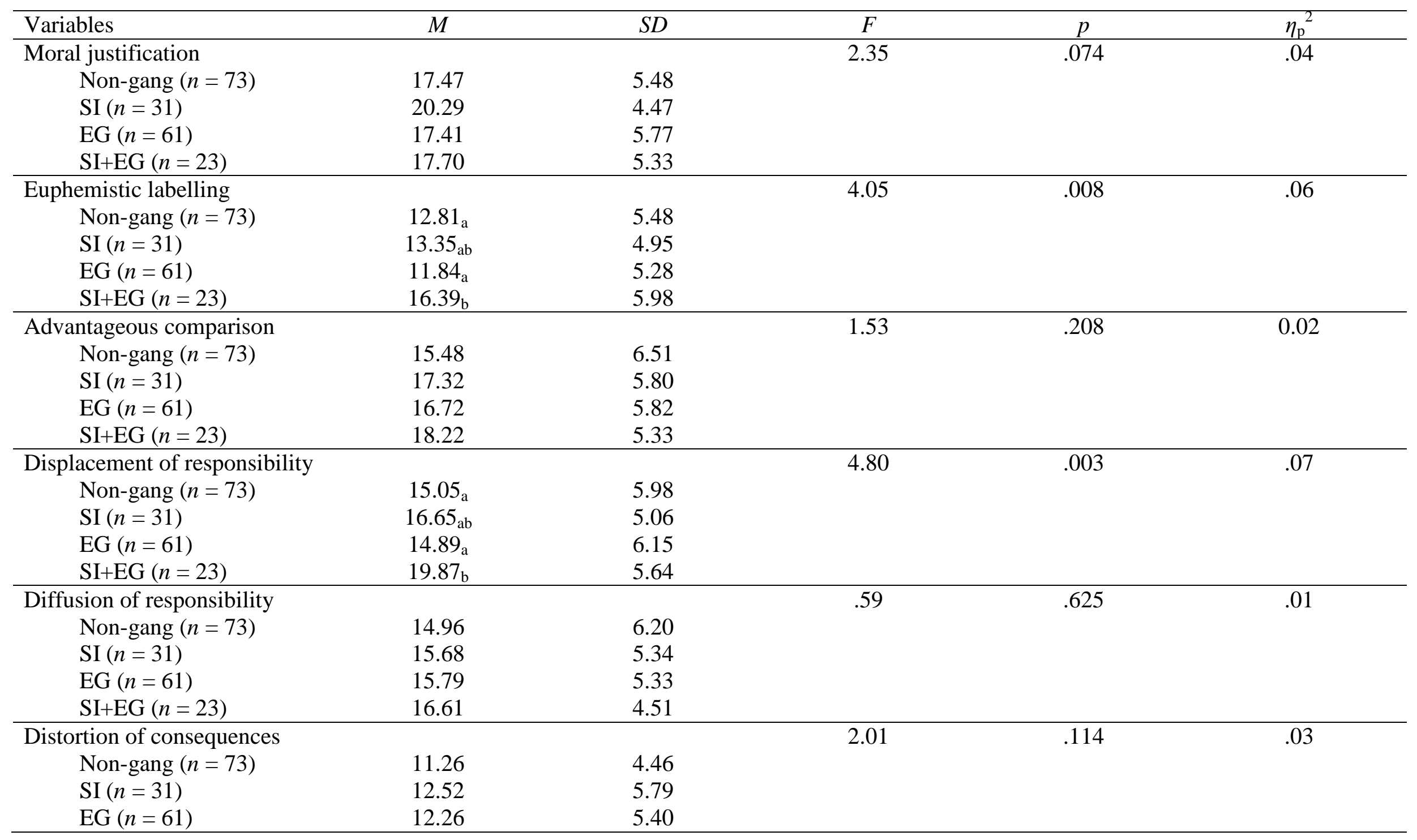


Running Head: STREET GANG MEMBERS IN CUSTODY

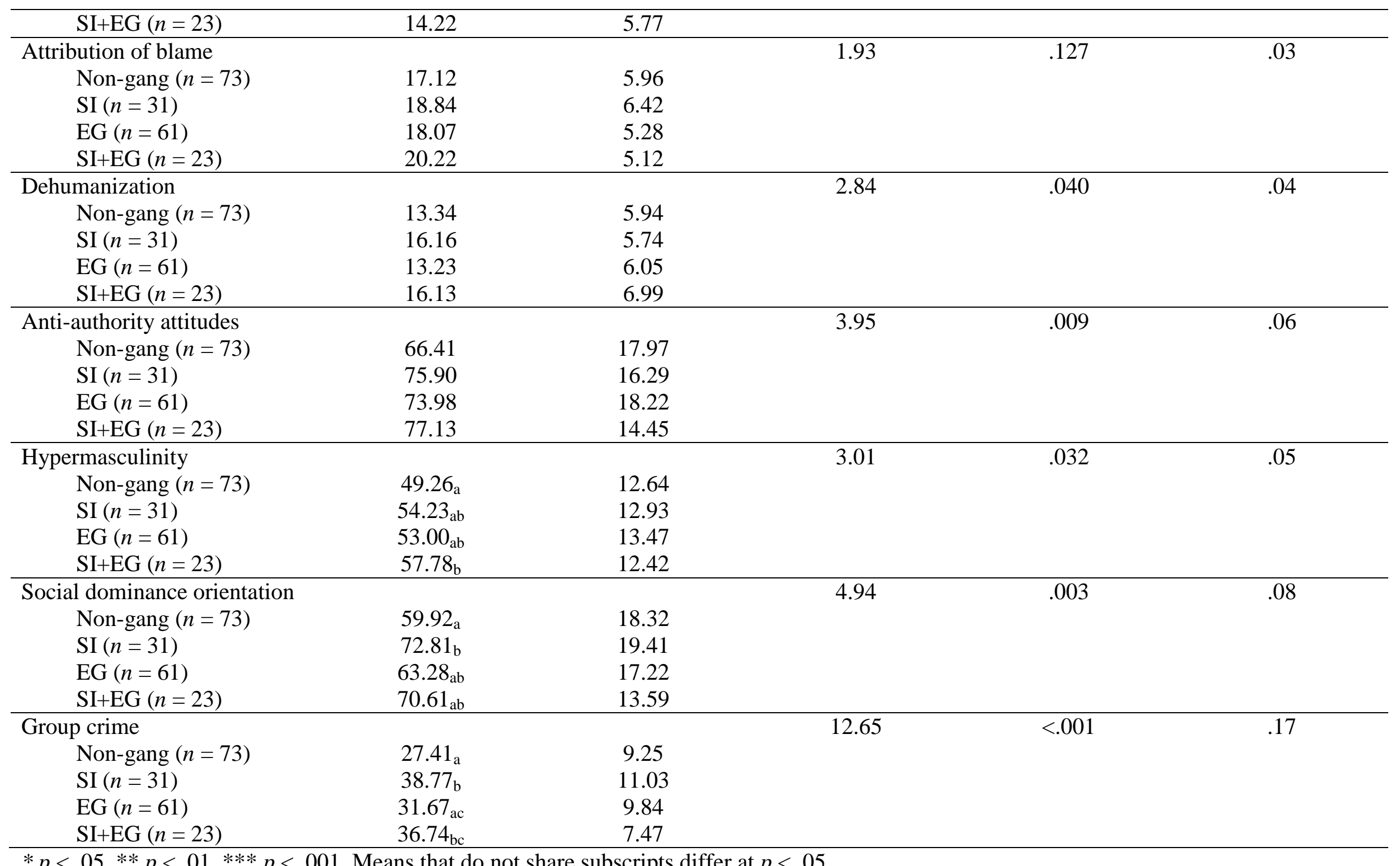




\section{Running Head: STREET GANG MEMBERS IN CUSTODY}

SI = self-identified gang members not fitting the Eurogang definition; EG = gang members fitting the Eurogang definition but not self-identified; SI+EG = self-identified gang members fitting the Eurogang definition. 
Running Head: STREET GANG MEMBERS IN CUSTODY

Table 5. Variables predicting group membership in descending order of importance

Predictor variable

Canonical Correlation Coefficient

Group crime

.82

Social dominance orientation

Displacement of responsibility

Anti-authority attitudes

Dehumanisation

.38

Hypermasculine values

.36

Euphemistic labelling

Attribution of blame

.30

Distortion of consequences .28

Moral justification .27

Advantageous comparison

Diffusion of responsibility 